\title{
A.В.Ільӥна
}

кандидат мистеитвознавства, молодший науковий співробітник Інституту філософї імені Г.С.Сковороди НАН України

\section{ІДЕЯ ЧИСТОТИ В ТРАНСЦЕНДЕНТАЛЬНІЙ ТРАДИЦЇ̈ ЗАХІДНОЄВРОПЕЙСЬКОЇ ФІЛОСОФСЬКОї ДУМКИ}

Проблема чистоти для сучасної гуманітаристики $є$ одним із найбільш критикованих сюжетів, який репрезентує найпоказовіші домагання і прагнення модерного дискурсу [15]. Зокрема, цю критику спрямовано проти моральних конотацій ідеї чистоти, з огляду на нездійсненність вимог останньої, а також на породжувані настановою на чистоту феномени насильства. У філософській царині ідеї та поняття, пов'язані з феноменом та концептом чистоти, піддаються критиці з огляду на те, що вони, по-перше, через власну незадовільність викривають некогерентність відповідних філософських систем (що прямо чи непрямо грунтуються на принципі чистоти) i, по-друге, замикають останні всередині власних ресурсів, не дозволяючи їм реагувати та відкликатись на зовнішні фактори. У підсумку системи зазнають кризи i, як наслідок, або руйнуються, або мусять радикально трансформуватися: таким $\epsilon$ урок екзистенціалізму, постмодерних філософій та інших критик «метафізики чистоти». Але чи не маємо ми справу також і з третім варіантом розвитку подій: коли певний дискурс якщо не здійснює, то, принаймні, вказує на можливості самоперевершення, радикалізації та гіперболізації власних настанов? Отже, актуальним (і значно менш вивченим) питанням видається переосмислення можливостей i креативних потужностей самої «парадигми чистоти». До такого аналітичного ракурсу спонукає теоретичний спадок трансцендентальної філософії, котра, з одного боку, підсумувала та оприявнила засади західноєвропейського типу мисленнєвого дискурсу, а 3 іншого - визначила собою інтелектуальний ландшафт європейського сьогодення (і не лише філософського).

Проблема чистоти в трансцендентальному дискурсі є достатньо артикульованою в теоретичних та історико-філософських дослідженнях 
і розглядається у вельми різних своїх ракурсах та іпостасях. Наприклад, до теми чистоти (на противагу «забрудненості»-souillure), як іiі представлено в німецькому ідеалізмі, звертається відомий історик філософії Алексіс Філоненко [12]. Займаючи критичну позицію щодо тлумачення даної пари концептів у філософіях Канта та Гегеля (зокрема, викриваючи позірність радикальної відмінності позиції Гегеля 3 цього питання щодо кантової концепції - відмінності, постульованої самим Гегелем), Філоненко аналізує причини та параметри критики, яку Гегель спрямовує на кантівську «хибну чистоту». Вельми важливим, хоч i, здавалося б, тривіальним висновком дослідника є думка, що «Кант бачить в чистоті радше ідеал, ніж факт» $[12,482]$. Очевидність цього твердження не виключає його вагомості: адже саме можливісність, als-ob настанова кантівської думки впритул підводить до розуміння смислу і усвідомлення значущості категорії чистоти в їі трансценденталістському тлумаченні. Цікаву інтерпретацію сюжету чистоти пропонує М.Турньє. Ïї змістовний аналіз дається у статті Марка Янга [14]. Тут чистота в неочікуваний спосіб протиставляється невинності (потенціальному становленню) як модусу чистоти, що виявився забутим, по-насильницьки редукованим в рамках платонівсько-кантівської лінії західноєвропейського філософування $[14,62]$. Серед робіт, присвячених темі чистоти, як актуальну для теми даної розвідки особливо хотілося б відзначити монографію Іена Маккензі [10]. Ідея чистої критики, що є темою цієї роботи, відповідає основній настанові трансцендентальної філософії. Маккензі звертає увагу на своєрідний парадокс чистої критики, оскільки критика - принаймні в рамках сучасних мисленнєвих трендів - $\epsilon$ насамперед критикою феноменів, пов'язаних з імплікаціями чистоти. «Чого можна досягнути, адресуючись до ідеї чистої критики, коли може бути правдоподібно стверджено, що чистота є саме тією проблемою, до якої має звертатись критика? Дійсно, від іiі походження в Кантовому славетному тексті, ідея критики була встановлена проти тих догматичних захисників чистого розуму, яким не вдалося поставити під питання власні межі та сили розуму» $[10, \mathrm{X}]$. Але вимога чистоти зумовлена тим, що «нечистій критиці ніколи не вдаватиметься перевершити критиковане» $[10, \mathrm{XVII}]$. I ще два моменти концепції Маккензі привертають увагу. По-перше, «критика стає чистою, коли вона стає повністю відповідною собі» $[10, \mathrm{X}]$. Таким чином, критика передбачає таку ж саму замкненість, як і критикована нею з цього 
самого приводу чистота. I, по-друге, дослідник настільки розширює горизонт питання, що говорить про «філософію як чисту критику» $[10,36]$. Це нагадує про певне узагальнення, здійснюване трансценденталізмом (як квінтесенцією критичного мислення) щодо західноєвропейської філософії, і водночас підкреслює вагомість визначального для трансцендентальної думки поєднання критичності та чистоти.

Мета статті - проаналізувати значення і функції концепту чистоти в трансцендентальному дискурсі, найбільш репрезентативними в своїй строгості версіями котрого виявляються концепції I.Канта, Е.Гуссерля і Ж.Дерріда. Попри значущість морального аспекту тлумачення і застосування концепту чистоти в трансценденталізмі, я зосереджую увагу на теоретичному ядрі його фактичної або можливої тематизації в трансцендентальних концепціях, реконструкцію котрої провадитиму на засадах зівставлення поняття чистоти 3 його негативним «двійником»: поняттям порожності, або пустоти. Попри очевидні конотації до східних мисленнєвих традицій, які викликає використання концепту «пустота» у філософському тексті, моя робота передбачає строге дотримування рамок західної традиції філософської думки.

Філософська традиція Заходу не являє собою гомогенного утворення. Проте видається можливим і нерідко вельми доречним підходом звертатися до визначальних тенденцій та трендів, які характеризують західноєвропейську думку par exellence. Якщо в такій перспективі поглянути на метафізичний спадок, то з легкістю можна зробити висновок про щонайменше маргінальне положення, відведене категорії пустоти в тій мисленнєвій парадигмі, яку Ж.Дерріда називає «логоцентризмом». Західна метафізика керується ідеалом повноти: «Що $\epsilon$ все?»: таким $\epsilon$ визначальне питання досократиків, яке не втрачає актуальності протягом всієї історії західноєвропейської думки [4]. Ідея повноти пов'язана 3 таким концептуальним рядом, як буття і присутність, тим часом пустота, відповідно, конотує до ніщзо і відсутності. Цей останній ряд в рамках західноєвропейського філософського мейнстриму характеризується негативністю - причому негативністю не лише в логічному, а й в оцінковому розумінні цього терміна. Зважаючи на це, можемо зрозуміти, як і чому ідеї Ніщо, відсутності і т.п. цементують ті західнофілософські концепції, які відрізняють та відділяють себе від раціональноідеалістично-логічного ядра європейської думки. Насамперед тут варто вказати на теологічно-філософську апофатику, а також на 
увагу до ідеї Ніщо з боку екзистенціалістських мислителів. Нерідко спроби реабілітації Ніщо, наприклад, у філософіях А.Шопенгауера та М.Гайдеггера, пов’язані з рецепцією та екстраполяцією концептуальних мотивів східних традицій. Втім, зумовленість західного філософського дискурсу словником 3 першої лінії - позитивної (повнота-буття-присутність) призводить до того, що постулати альтернативних філософій формулюються мовою і за правилами «метафізики присутності» [16]. Остання передбачає також акцент на принципі Першопочатку. Тому важливо, що негативний ряд термінів не просто розглядається як вторинний, але це має місце в рамках такої мисленнєвої настанови, де вагомість первинного статусу постійно тематизується та експліцитно стверджується.

Але я б хотіла звернути увагу на те, що всередині панівної лінії західної метафізики міститься мотив, який і гармонійно узгоджується із законодавчим ядром логоцентристських постулатів, і при цьому уможливлює альтернативний спосіб філософування. Це мотив чистоти. Його наявність у філософському дискурсі спостерігається щонайменше починаючи від Платона, проте свого апогею він сягає в царині трансцендентальної філософії, в рамках котрої він отримує програмне значення. В даному дослідженні я проаналізую спосіб функціонування і таким чином намагатимусь визначити смислову специфіку і статус ідеї та, відповідно, концепту чистоти в трансцендентальній традиції філософського мислення. Якщо Кант надає трансцендентальному стилю мислення певного оформлення і доктринальної легалізації, а Гуссерль перетлумачує і радикалізує теоретичні засади кантового трансценденталізму, то Дерріда піддає гіперболізації визначальні принципи трансцендентальної думки. Ідея чистоти по-різному заломлюється в кожній з означених концепцій; цікаві смислові нюанси надаються також концепціями кантіанця С.Маймона, неокантіанця Г.Когена, а також феноменолога О.Фінка - одного з найближчих учнів і послідовників Гуссерля.

Оскільки тема чистоти є невичерпним ресурсом дослідницької роботи, то спершу варто обмежити коло питань, розв'язання яких визначатиме подальший напрямок міркувань. Отже, зафіксуємо наступні питання, що слугуватимуть дороговказом у розробці заданої проблеми:

1) В чому полягає специфіка мотиву чистоти, і як він співвідноситься з ідеєю пустоти?

2) В чому полягає апорія чистоти в трансцендентальному мисленні? 
3) Що відбувається з настановою на первинність у межах трансцендентального дискурсу і який вплив на це чинить ідея чистоти?

4) Яку саме альтернативу уможливлює дискурс чистоти в контексті поступу логоцентричної думки?

Всі три фундаментальні проекти трансценденталізму вибудовуються 3 огляду на проблематику чистоти. Кант апелює до проблеми чистого розуму та - корелятивно - чистого пізнання, Гуссерль в розбудові концепції чистої феноменології відштовхується від ідеї чистоти свідомості [17], Дерріда змушений визнати значущість для деконструктивного мислення настанови на чистоту мови (iї значущість сягає від суто емпіричних проблем «чистої французької», позбавленої, скажімо, англіцизмів, але також і внутрішніх «контамінацій», діалектизмів, до визначальної для Дерріда проблеми мовної ідіоми), що виливається в низку позначених проблемою чистоти сюжетів - гостинність, дарунок, прощення та ін. В той час як для Канта і Гуссерля поняття чистоти (чистого) має статус оперативного концепту, для Дерріда воно виявляється поняттям тематичним, якщо скористатися альтернативою, запропонованою О.Фінком. Тематизації концепт чистоти підлягає також у в філософській концепції Г.Когена, в рамках якої воно набуває програмного значення. У рамках кантівської традиції поняття чистоти виступає фактично синонімом поняття трансцендентальності, відповідно стає зрозумілим, наскільки ідея чистоти є вагомою для трансцендентального дискурсу. Іншим квазі-синонімом трансцендентальності є критичність, яка відповідно пов'язана з чистотою, адже критика означає очищення [18]. Гуссерль порівняно з Кантом навіть посилює значущість вимоги й принципу чистоти в межах власного філософського проекту. Йдеться про чисту феноменологію, чисту логіку: тобто прикметник «чистий» докладається до найбільш вагомих понять і тем гуссерлівської філософії. Що стосується Дерріда, то в ранніх роботах він начебто скептично ставиться до панування ідеї чистоти в логоцентричному дискурсі, але це, хай і в негативний спосіб, та все ж тягне впливовість концепту чистоти в рамках деконструктивного мислення. Крім того, критика, навіть якщо вона спрямована на чистоту, залишається вірною настанові на власну чистоту. А в контексті ж пізнього Дерріда ми взагалі можемо говорити про своєрідну апологію чистоти, але 3 урахуванням суттєвого перетлумачення сутності цієї категорії.

Зафіксуємо основні типи тлумачення чистоти, які зустрічаємо 
в трансцендентальній філософії кантового типу.

1)Чистота сутності, або «ейдетична». Цей варіант зберігає найбільше зв'язків із субстанціалістською парадигмою, оскільки вказує на чистоту речі, сутності, об'єкта - одним словом, певного, але узагальненого Що. Вельми значимий для гуссерлівського підходу, цей тип чистоти виказує амбівалентну орієнтованість феноменологічного дискурсу, що осцилює між граничною субстантивністю та чистою предикативністю. Те, що предикат чистоти характеризує полюс не Его, а Предмета, вказує - у випадку феноменологічної перспективи - на егологічне походження смислу Речі, точніше - речі в модусі смислу, на що вказує двоїстість процедури конституювання (створення та прояснення водночас). Крім того, чистота ейдосу $є$ зумовленою чистотою досягнення і сприйняття ейдосу [8, 171].

2)Чистота сингулярності - неповторність (а отже, простота) речі або події. Цей модус чистоти $є$ не надто специфічним для трансцендентальної парадигми. Проте, як досить переконливо зазначає Е. Штрекер - учениця Гуссерля і дослідниця його феноменології, - чистота, зумовлена трансцендентальною редукцією, це чистота партикулярних феноменів, що позбавляє трансцендентальну феноменологію здатності робити узагальнені твердження [13, 68-69]. Необхідність генералізації, як вважає Штрекер, компенсується ейдетичною феноменологією. Проте отримання чистих феноменів не здається мені вичерпною і навіть основною характеристикою результату трансцендентальної редукції. Але цікаво, що деррідіанське розуміння чистоти почасти пов'язане з сингулярністю: це стосується насамперед таких сюжетів, як ідіоматичність мови та непередбачуваність події.

3)Чистота структури, що пов'язана не $з$ гіперболічним очищенням Що, як у випадку ейдетичності, але з очищенням вiд будbяких Що, котре тягне гіперболу Як-позиції, тобто абсолютизацію відношення на тлі редукції Речі. Окремим випадком цього модусу чистоти - a, точніше, шляхом до його здійснення - $є$ принцип автореферентності. Цей принцип реалізується внаслідок трансцендентальної редукції, коли інтенційним предметом феноменологічної свідомості стають власне акти цієї свідомості (і цей наслідок видається мені суттєвішим за той, що його акцентує Штрекер).

4)Інтенційна чистота. Цей модус почасти перекривається 3 попереднім - структурним, але має і суттєву відмінність. Інтенційний 
модус - найбільш характерний і специфічний для трансцендентального дискурсу варіант розуміння і оприявлення ідеї чистоти. Інтенційна чистота - це, власне, та чистота для..., що зумовлює певний зсув в інтерпретації пари понять «форма - зміст». Чистота тут означає потенційну виповненість і виявляється у беззастережній відкритості Іншому - Іншому, що може бути представлений у вигляді досвіду, значення або смислу. Цьому типу чистоти відповідає не лише інтенційна свідомість, але й концепт прийдешнього (avenir), визначальний для дискурсу «пізнього» Дерріда.

Спираючись на наведену типізацію, перейдемо до розгляду окремих питань, що стосуються проблеми дескрипції та визначення семантичного та функціонального статусів ідеї (поняття) чистоти в трансцендентальній думці.

Щодо співвідношення ідей чистоти і пустоти зауважимо, що в словнику трансценденталістів присутні обидва терміни. Критики ідеї чистоти нерідко не розрізняють чистоту та пустоту - свідомо або несвідомо. У випадку трансцендентального дискурсу чистоти вони і мають рацію, і потерпають фіаско, адже, як і всі трансцендентальні концепти, чистота має амбівалентні значення і функцію. Ідея чистоти ніби втручається в опозицію «пустота-повнота». 3 одного боку, чистота є позитивною як те, що має сприяти виповненню, як умова можливості повноти, і в цьому вона протистоїть пустоті. Проте, з іншого боку, чистота перебуває на боці пустоти в тому, що стосується актуального стану речей, і вона максимально наближається до пустоти в контексті опозиції «форма і зміст». Вочевидь, чистота тяжіє до формального аспекту. Звернімо увагу на те, що саме трансцендентальна філософія приділяє значну увагу проблемі синтаксису. А стосовно філософії Дерріда можна говорити навіть про артикульований зв'язок чистоти і синтаксичності [19]. Келлі Олівер, відома американська дослідниця, зазначає, що концепт чистоти у Дерріда є пов'язаним із чистотою концептів: цим Дерріда - згідно 3 іiі інтерпретацією - опонує історикофілософському тренду пов'язання чистоти з природою, на противагу зіпсованості культури $[11,98]$. Але настанова на «синтаксизацію» чистоти властива кантово-гуссерлівській лінії філософування в цілому. Проте водночас трансцендентальне мислення спрямоване на суттєве перетлумачення опозиції форми і змісту, і в цьому перетлумаченні не останню роль відіграє ідея чистоти. Далі цей сюжет буде розглянуто докладніше. 
Наступна тема, на яку варто звернути увагу в контексті проблеми чистоти, це питання трансцендентального зсуву, котрий полягає у переході від субстантивістської парадигми догматичної метафізики (позначимо ії як парадигму «Що»), до такого типу мислення, в якому ключову роль відіграють ідеї відношення та відмінності (назвемо цей підхід парадигмою «Як»). Ідея пустоти породжує концепт, що $є$ субстантивом, тобто $є$ певним «Що». Негативним відповідником цього концепту - але також субстантивним - $є$ поняття Ніщо, яке, судячи зі статистики звернень, виявилося більш прийнятним для метафізичного дискурсу, ніж поняття пустоти [20]. Альтернативою пустоти є повнота, тоді як альтернативою пустоти в модусі Ніщо можуть бути як Все, так і Дещо. Пустота i $\mathrm{Bce}-$ це полюси граничних визначень для будь-якого Що (в результаті вони сходяться, оскільки Все дає не більше простору для смислового наповнення речі, ніж Ніщо). Ідея Дечого більш складна. Вона залишається майже пустою, але забезпечує той мінімум перспективи певного, можливого сюжету, який є достатнім для конституювання смислів, тобто - для функціювання мислення. Особливу значущість концепт Дещо (Etwas) має для трансцендентально-феноменологічної думки. Проте йдеться про мінімальну, але субстантивність [21].

Втім, значно суттєвіша відмінність вимальовується, якщо поглянути на природу власне концепту чистоти, яким він постає в трансцендентальному дискурсі. I «чисте», і «трансцендентальне» виступають як предикати, що прикладаються до різних «Що»: чисте знання, чисті уявлення, чиста форма, чисті споглядання, чисте мислення, чисті числа, чиста фантазія, чиста можливість, чиста присутність тощо. Цікаво зазначити, що Дерріда навіть частіше за прикметник «чистий» застосовує відповідний прислівник (purement). Отже, запропоноване визначення «парадигма «Як» має буквальне підтвердження в деррідіанському дискурсі, адже прислівник більш суттєво дистанціюється від прив'язки до субстантиву, ніж це може зробити прикметник.

Якщо пустота є радше онтологічною характеристикою, то чистота пов'язана 3 порядками мислення та моралі, тобто входить в логічний та етичний дискурс, спільною рисою яких є пов'язаність із цариною суб' єктності.

Пов'язаність чистоти із «Як»-парадигмою і водночас із суб'єктною цариною узгоджується 3 тим фактом, що трансцендентальна 
суб' єктивність (відповідно до Кантової настанови, яка відтворюється і Гуссерлем, і (по-своєму) Дерріда) має функціональну природу: вона не субстантивується, не може бути схопленою та перетворитися на предмет. 3 цих самих причин трансцендентально-феноменологічне Я не підлягає редукції. В той час як чистота $є$ характеристикою суб'єктного полюсу, який в трансцендентальному мисленні репрезентує формальне Начало, пустота або повнота є характеристиками змісту - полюсу значень або смислів, який у рамках трансцендентального підходу заступає місце об'єкта.

Оскільки парадигма «Як» передбачає методологічний акцент, то трансценденталізм, а отже, і чистота, як один із його визначальних предикатів, пов'язані, насамперед, з проблемою методу. Предикат чистоти пов'язаний також 3 категорією можливості, котра, як відомо, є вагомою складовою трансцендентального дискурсу. Чистота має характер регулятиву - ідеальної настанови на очищення - і оприявнюється лише у вигляді процесу. Йдеться радше про телеологію очищення, що передбачає певну настанову і набір методологічних процедур. Г.Коген навіть вживає словосполучення «метод чистоти». 3 метою певною мірою конкретизувати це питання назву найбільш відомі принципи 3 царини трансцендентальної методології, які пов'язані з ідеєю очищення. Найбільше таких принципів в експліцитній подачі віднаходимо у Гуссерля. Це, насамперед, принципи редукції та епохе. Редукція є очищенням від передумов, і при цьому вона сама проходить кілька стадій квазіочищення (найбільш наочним прикладом тут є співвідношення ейдетичної та трансцендентальної редукцій). Епохе - тобто утримання від судження - залишає нас у чистоті можливості, адже втручання емпіричного вибору руйнує трансцендентальну чистоту. Цей принцип відтворює Дерріда в рамках свого вчення про апорію. Також слід згадати про постульовані Гуссерлем «модифікації нейтральності», що передбачають можливість «просто мислити» здійснюване поза участю у здійсненні. Варто вказати і на мотив автореферентності- принцип, спільний для всіх трансцендентальних філософій, що полягає у перетворенні певної операції на власний об'єкт. Авто-референтність тягне очищення форми від зовнішнього змісту, конституюючи зміст з формальних ресурсів. 3 ідеєю чистоти також пов'язаний принцип гіперболічності, оскільки тяжіння трансцендентальної думки до чистоти є гіперболічним і оскільки певну гіперболічність закладено в регулятивній ідеї чистоти: як 
неможливість емпіричного здійснення та як настанову на перманентне вдосконалення (очищення). I, нарешті, згадаємо таку пару методологічних концептів, як прояснення і стирання. Перший iз них належить гуссерлівському дискурсу. Другий належить Дерріда і набуває програмного значення, оскільки вказує на походження метафори сліду (як відомо, концепція сліду є одним зі стрижневих моментів філософії деконструкції). В який спосіб пов'язані між собою стирання та прояснення? По-перше, стирання, як варіант редукції, покликане очистити від нашарувань те, що має статус остаточності, або Першопочатку. В цьому значенні стирання дорівнює проясненню. Свого роду «стиранням» феноменологія просувається до відкриття чистого Я як «феноменологічного залишку» [22]. Проте у випадку Дерріда, як зрозуміло з самого поняття «слід», сама ідея початку виявляється щонайменше підданою стиранню. Те, що вдається з'ясувати, цілком належить процесу стирання і не $\epsilon$ оригінальним, але лише вказує на можливість оригіналу, котрий сам по собі перебуває поза зоною мисленнєвої досяжності.

Але чи не змінює докорінно парадигма «Як» логоцентристські уявлення про значимість статусу первинності? Адже на перший план виходять мотиви, які, згідно з традицією «метафізики присутності», мали б розглядатися як похідні. Навіть усамостійнення ідеї методу свідчить на користь цієї радикальної зміни. Також і принцип чистоти виявляє свій засадничо залежний характер.

У межах цієї узалежненості маємо зробити важливе розрізнення: чистота вiд чогось і чистота для чогось. В цьому контексті я повернуся до попередньо означеної проблеми деконструкції опозиції форма-зміст, що здійснюється в межах трансцендентального дискурсу. В горизонті цього питання найбільш виразно вимальовується відмінність між чистотою та пустотою. Адже очищення для за означенням передбачає суто функціональний, принципово несамодостатній статус чистоти, бо очищення відбувається лише задля того, щоб полюс суб'єктивності набув можливості працювати зі смислами, тобто - зі змістом, що наповнюватиме, виповнюватиме формальні структури мови, розуму, мислення або свідомості. Більше того, по суті, лише чистота думки гарантує (або принаймні обіцяє) повноту змісту. Г.Коген заперечує легітимність протиставлення чистоти змісту, внаслідок якого чисте мислиться як пусте. Натомість він застосовує предикат чистоти до самого змісту $[3,117]$ (а не тільки до мислення або пізнання) і впроваджує 
нову опозицію: «чистий зміст - нечистий зміст». Здавалося б, він таким чином субстантивує чистоту, приписавши ії квазі-предметному полюсу. Проте Коген зберігає за чистотою рису функціональності, дієвості і процесу, оскільки стверджує, що «чистий поширюється на нечистий зміст, щоб перетворити його на чистий». Схожим чином Гуссерль включає зміст до царини синтаксису, розрізняючи синтаксичні форми і синтаксичні змісти. Але найпершим трансцендентальним закликом до суттєвого перегляду відношення між формою і змістом на грунті перспектив дискурсу чистоти є знаменитий афоризм Канта «Думки без змісту пусті, споглядання без понять сліпі» $[2,155]$. Як і у Когена, пустота тут є негативною стороною справи, а вирішує проблему ідея чистого знання (згадаємо, що інтенцією трансцендентальної логіки - на відміну від звичайної, формальної - є розрізнення знання чистого та емпіричного, замість редукції змістовного знання до пустої формальності).

Більш поблажливо до пустоти ставиться Гуссерль. Коли він розрізняє пусті та виповнені інтенції, то в першому випадку йдеться не про якісь невдалі спроби чи хибні змісти, але лише про змісти, які наразі не отримали здійснення в актуальному переживанні споглядання, а значить, пов’язані з горизонтом можливостей. I в цьому випадку предикат пустоти знову-таки стосується характеристик не свідомості, а змісту. Пустота в даному аспекті виявляється корелятом чистоти, який стосується характеристик полюсу предмета. Це буде «пустота для» (корелятивно «чистоті для...») - тобто телеологічно зумовлена пустота: «пустота, що є не Нічим, але пустотою, що має бути виповненою» $[9,42]$. Отже, якщо Коген екстраполює посутньо суб'єктну властивість чистоти на зміст, то Гуссерль приписує пустим змістам властивість «бути для...», тобто де факто інтенційну властивість, яка первинно $є$ властивістю чистоти як предикату свідомості (свідомості за означенням інтенційної - згідно з вимогами трансцендентального дискурсу). А щодо феноменологічного Я читаємо в «Картезіанських медитаціях», що воно «не є пустим полюсом тотожності» [1]. Однак це не заважає йому бути чистим!

Філософський словник Дерріда включає велику кількість конотацій до ідеї пустоти: насамперед це розрив та інтервал, але також варто згадати метафоричні концепти пустелі (désert) та безодні (abîme), що наповнюють його тексти. Проте звернімо увагу, що проблема Іншого, яка пронизує деррідіанську думку, не дозволяє 
абсолютизувати ці поняття і підказує таке їхнє тлумачення, котре нагадує щойно визначену характеристику первинно не пустоти, а чистоти: від чогось і для чогось.

Таким чином, чистота мислення або свідомості уможливлює повноту знання або смислу. Це стосується кантівсько-гуссерлівської перспективи. Дещо інакше розглядає цю проблему Дерріда. Справді, чистота мови і для нього залишається умовою можливості смислів в царині інтерпретації, а чистота суб'єкта дорівнює його відкритості абсолютно Іншому. Втім, тема чистоти в екстраполяції на мовну царину не створює, але виявляє певну проблему, що є спільною для всіх трансцендентальних дискурсів чистоти, при цьому байдуже, яким є центральний концепт, якому предикат чистоти буде приписано: розум, свідомість чи мова. Цією проблемою є своєрідна апорія чистоти, яка грунтується на більш загальній трансцендентальній апорії: трансцендентальний суб'єкт покладається автономною і самодостатньою структурою; натомість його функціональна природа виявляє його сутнісну несамодостатність, апріорну спрямованість на певне Що, яке є принципово іншим щодо суб'єкта мислення, пізнання, мовлення або письма. Щодо теми чистоти ця апорія модифікується таким чином. Згідно 3 певним стереотипом, чистота стало асоціюється з і ставиться в залежність від вимоги простоти. Деконструкція, викриваючи всі недосконалості та неспроможності принципу простоти, не відмовляється при цьому від чистоти, але ставить іiі в парадоксальну позицію: запроваджується ідея «чистої відмінності», що в контексті вимоги простоти здається руйнівним оксюмороном. Чистота мови - це і є чистота відмінності, як у випадку внутрішнього визначення мови як системи відмінностей, так і $з$ огляду на принципову несамостійність мови в перспективі зовнішніх відношень: між мовою і позамовним простором «дійсності», а також (більш складний варіант) між мовою, світом і мовцями. Але виявляється, що подібну несамостійність мають і Кантові розум, розсудок або мислення, які мають сенс лише в контексті своєї відмінності від досвіду або ноуменального «Що». Тим більше це стосується гуссерлівської свідомості: iї основна характеристика інтенційність - означає бути «свідомістю про...».

Отже, всі три носії чистоти - чистий розум (або мислення), чиста свідомість і чиста мова неначе одразу передбачають порушення чистоти. Та й перший з трьох проектів «очищення» - Кантова критика - передбачає постановку під питання легітимності і 
спроможності чистого розуму. Адже оскільки розум по суті не може бути не чистим (адже він не має справу безпосередньо 3 феноменами досвіду), то концепт «чистого розуму» $\epsilon$ нонсенсом, оскільки чистота - це настанова на очищення і без «не-чистого» не має сенсу. Крім того, наявність антиномій засвідчує позірність чистоти розуму, а отже, доводить неспроможність останньої. I, нарешті, чистий розум протистоїть чистому розсудкові, чистота якого визначається у співвідношенні 3 не-чистотою емпірії, а отже, передбачає не-чистоту як умову власної можливості.

Тепер, зважаючи на попередні зауваження про регулятивність та предикативність чистоти, можна поставити питання: чи не заперечує чистота можливості простоти, і - більш жорстко - чи не передбачає чистота свою протилежність як умову можливості власного існування? Як пояснює Сафаа Фаті, авторка відомого фільму «D'ailleurs Derrida», «концепт «чисте» у Дерріда є тим, що дозволяє мислити контамінацію» [7, 31]. Порівняємо це $з$ думкою, що іiі висловлює в «Логіці чистого пізнання» Г. Коген: перетворення нечистого у чисте $\epsilon$ «неминучим відношенням, яке має зі змістом «чисте». Без нього [цього відношення. - А.І.] «чисте» втратило б сенс» (цит. за [3, с. 117]).

Звичайно, значущість і багатоаспектність теми не дає можливості охопити в рамках однісї статті всі навіть найбільш фундаментальні проблеми, пов'язані з дискурсом чистоти в трансцендентальній філософії. Поза розглядом залишилися такі важливі сюжети, як онтологізація чистоти і повернення теми Ніщо у феноменології О.Фінка, як ідея очевидності та ії убудованість в проблематику неопосередкованості (котра - поряд із простотою - $є$ невід'ємним аспектом тлумачення чистоти), як принцип апорії, котрий порівняно з очевидністю являє собою інший полюс реалізації принципу неопосередкованості, як тема феноменологічного неподвоєння світу, можливість якого зумовлена редукцією ідеї Першопочатку, тощо.

Як висновки до проведеного дослідження хотілося б відзначити такі позиції.

Запропонований в даній роботі аналіз дозволив виявити і показати спосіб, у який ідея чистоти в своєму трансценденталістському оприявленні виявляється спроможною окреслити альтернативні концептуальні (і навіть ширше - парадигмальні) можливості і ресурси всередині самої західноєвропейської традиції. I цей спосіб сам по собі становить певну альтернативу щодо логоцентрист- 
ських кліше. Адже, як відомо, західна культура бінарно-опозиційного мислення задля побудови альтернативних моделей часто-густо послуговується методом перегортання опозицій, який викривається та критикується філософією деконструкції. Натомість трансцендентальний поворот пропонує не переворот, а радше зсув, що змінює не Що на Ніщо, але Що на Як - зсув, який не в останню чергу уможливлюється ресурсами дискурсу чистоти. Параметри «догматичної» метафізики визначаються субстантивними координатами «що-ніщо-дещо», 3 яких позитивне начало, Що (певною мірою Дещо) доповнюється ідеями повноти і присутності, утворюючи концептуальне ядро логоцентричного мислення. Ідея чистоти як методологічна настанова і телеологічний регулятив уникає субстантивації i, відтак, виступає характеристикою не-предметних царин трансцендентального мислення, трансцендентальної свідомості або трансцендентальної мови. Натомість пустота виявляється пов'язаною 3 цариною змісту і долається завдяки чистоті, котра сприяє виповненню завдяки параметру інтенціональності. Чистота від і чистота для становлять два основних модуси функціонування ідеї чистоти в трансцендентальній думці. Аналіз трансценденталістського дискурсу дозволив виявити наявність у ньому чотирьох основних типів тлумачення чистоти. Це «ейдетична» чистота, чистота сингулярності, чистота структури та інтенційна чистота.

Ідея чистоти виявляє деконструктивний потенціал, що ставить під питання опозицію «повнота-пустота», пропонуючи альтернативний мисленнєвий підхід і стиль, скерований настановою на відношення та відмінність на противагу презумпції Речі, яка визначала до-критичне філософування на теренах західної традиції. Суттєвим історико-філософським результатом є віднаходження такої радикальної альтернативи не в позначеному зовнішніми впливами мисленнєвому середовищі, і не у випадкових «відхиленнях від норми» 3 погляду західноєвропейського інтелектуального мейнстриму, але в самому осерді, в інтелектуальному ядрі західноєвропейської думки: в рамках трансцендентальної традиції філософського мислення. 


\section{ЛІТЕРАТУРА ТА ПРИМІТКИ}

1.Гуссерль Э. Картезианские размышления / М. : Академический проект, 2010. - 229 c.

2.Кант И. Критика чистого разума / М. : Мысль, 1994 - 592 с.

3.Пома А. Критическая философия Германа Когена / М. : Академический Проект, 2012. - 319 с.

4.Пролеев С. История античной философии. - М.: Рефл-бук; К. : Ваклер, 2001. $-512 \mathrm{c}$.

5.Шопенгауэр А. Мир как воля и представление // Шопенгауэр А. О четверояком корне... Мир как воля и представление. - Том 1. Критика кантовской философии / Пер. с нем. М. Левиной. - М. : «Наука», 1993. - 672 с.

6.Coopman, C. Rorty's Moral Philosophy for Liberal Democratic Culture // Contemporary Pragmatism - 2007. - Vol. 4, №2. - Pp. 45-64.

7.Derrida, J., Fathy, S. Tourner les mots - Au bord d'un film. Paris: Galilée, 2000. - $170 \mathrm{p}$.

8.Downes, C. On Husserl's approach to necessary truth // Readings on Edmund Husserl's Logical Investigations / ed. Mohanty, J. - Springer Science \& Business Media, 2012. - Pp. 162-178.

9.Husserl, E. Analyses concerning passive and active synthesis. Lectures on transcendental logic / tr. by // A. J. Steinbock. - Dordrecht:Kluwer., 2001. - 661 p.

10.Mackenzie, I. The Idea of Pure Critique. - Bloomsbury Academic, 2004. $160(+\mathrm{XXVI}) \mathrm{p}$.

11.Oliver, $K$. Animal Lessons: How They Teach Us to be Human. - Columbia University Press, 2009. - $364 \mathrm{p}$.

12.Philonenko, A. Note sur les concepts de souillure et de pureté dans l' idealism allemend // Les Études philosophique. - 1972. - №4. - Pp. 481-493.

13.Ströker, E. Husserl's Transcendental Phenomenology / tr. by Lee Hardy. Stanford University Press, 1993. - 237 p.

14.Yang, M.Z. Thus Spoke Michel Tournier: Innocence as Antidote to Purity and Constant Becoming as Way of Life // International Journal of Humanities and Social Science. - 2014. - Vol. 4, No.1. - Pp.62-65.

15.Крім того, навіть у рамках сучасних теорій взаємні закиди нерідко базуються на критиці ідеї чистоти, зокрема - чистоти в контексті царини моралі. Так, відома американська дослідниця Колін Купман вказує на те, що критичний імпульс по відношенню до «морального ядра ліберальної культури» здатний поєднати таких далеких мислителів, як Р. Рорті, Ч. Тейлор, М. Фуко, котрі поділяють «сумніви... щодо «чистоти» та «пустоти» сучасної моральної теорії» $[6,47]$. Звернімо увагу на наявний в цитаті мотив зближення характеристик чистоти та пустоти, критиці якого буде приділено значну увагу в даній роботі. 
16.Застерігаючи від такого результату, А.Шопенгауер зазначає, що «протилежний погляд... поміняв би знаки, і суще виявилось би для нас нічим, а ніщо сущим... положення Емпедокла, що подібне пізнається лише подібним, саме в даному випадку позбавляє нас будь-якого пізнання» $[5,501]$.

17.Через обмеженість можливого об'єму в цій роботі я не зупинятимусь на такому важливому питанні феноменологічної теорії, що безпосередньо стосується теми трансцендентальної чистоти, як розрізнення між інтенційною свідомістю (джерелом, творцем та носієм змістів свідомості) та феноменологічним Его (константним фундаментом, що гарантує єдність трансцендентальної свідомості), що є вихідною дистинкцією в царині трансцендентальної суб'єктивності. Окрему увагу цій проблемі буде приділено в наступних роботах.

18.У першій «Критиці» Кант риторично запитує, «що за скарб ми маємо намір лишити нащадкам у вигляді метафізики, очищеної за допомогою критики» $[2,21]$, і зазначає, що критика «може слугувати не розширенню, а лише очищенню розуму» $[2,44]$.

19.Синтаксис в даному випадку будемо розуміти не в буквальному значенні (беручи до уваги лінгвістичний контекст), а більш загально, як формальну царину, відповідальну за продукування, відтворення і використання мисленнєвого апарату.

20.Можливою причиною популярності Ніщо мені видається його перспективність у логічній царині - тоді як метафора пустоти прив'язана до просторового ряду метафор і, відтак, обмежується сферою онтології речей.

21.Про визначальність субстантивістської орієнтації західноєвропейської метафізики свідчить характерний спосіб запитування, орієнтований на модальність «що»: отже, в питанні «що є все?» вельми репрезентативним і програмотворчим виявляється не тільки другий, але й перший елемент.

22.Маккензі визначає чистоту як «результат методу віднімання: чисте $\epsilon$ тим, що залишається після того, як домішки [impurities] будуть відсунуті» $[10, \mathrm{XIII}]$.

Ільїна А.В. Ідея чистоти в трансиендентальній традиції західноєвропейської філософської думки

В статті аналізується значення концепту чистоти в трансцендентальному дискурсі філософської думки і розкриваються його основні характеристики. Розглядається відношення між поняттями чистоти та пустоти в опозиції «форма-зміст», котра зазнає сугтєвого перегляду в рамках трансцендентальної традиції. Деталізується аспект функціювання ідеї та поняття чистоти у трьох панівних концепціях трансценденталізму: філософських проектах Канта, Гуссерля та Дерріда, в кожному з яких чистота характеризує 
фундаментальні царини філософської проблематизації - відповідно, розуму, свідомості та мови. Показується, яку роль відіграє поняття чистоти як принципово предикативний концепт (i як синонім поняття трансцендентального) в реалізації парадигмального «зсуву», пов'язаного з антисубстантивістською орієнтацією трансцендентального мислення. Це призводить до зміни акцентів у філософському запитуванні з догматико-метафізичного «Що» на критично-трансцендентальне «Як». У статті визначаються різні способи тлумачення чистоти в трансцендентальному дискурсі: ейдетична чистота, чистота сингулярності, чистота структури та інтенційна чистота.

Ключові слова: чистота, трансцендентальне мислення, пустота, свідомість, інтенційність, критика, редукція.

Ильина А.В. Идея чистоты в трансцендентальной традищии западноевропейской философской мысли

В статье анализируется значение концепта чистоты в трансцендентальном дискурсе философской мысли и раскрываются основные его характеристики. Рассматривается отношение между понятиями чистоты и пустоты в оппозиции «форма-содержание», которая подвергается существенному пересмотру в рамках трансцендентальной традиции. Детализируется аспект функционирования идеи и понятия чистоты в трех господствующих концепциях трансцендентализма: философских проектах Канта, Гуссерля и Деррида, в каждом из которых чистота характеризует фундаментальные области философской проблематизации - соответственно, разума, сознания и языка. Показывается, какую роль играет понятие чистоты как принципиально предикативный концепт (и как синоним понятия трансцендентального) в реализации парадигмального «сдвига», связанного с антисубстантивистской ориентацией трансцендентального мышления. Это приводит к смене акцентов в философском вопрошании с догматико-метафизического «Что» на критически-трансцендентальное «Как». В работе определяются основные способы трактования чистоты в трансцендентальном дискурсе: эйдетическая чистота, чистота сингулярности, чистота структуры и интенциональная чистота.

Ключевые слова: чистота, трансцендентальное мышление, пустота, сознание, интенциональность, критика, редукция.

Ilyina A.V. Idea of Purity in Transcendental Tradition of West-European Philosophical Thought.

The article deals with analysis of meaning and revealing of main characteristics of concept of purity in transcendental discourse of philosophical thought. Relation between concepts of purity and emptiness is discussed regarding "form-content" opposition, which undergoes essential reconsideration within the transcendental 
tradition's framework, as present article intends to show. The paper specificates the question of function of idea and notion of purity in three cardinal transcendental projects: these by Kant, Husserl and Derrida. Within each of them purity defines the fundamental areas of philosophical problematic, that is of reason, consciousness and language respectively. The role, which the notion of purity as a fundamentally predicative concept (and as a synonym of the concept of transcendental) plays in realization of paradigmatic shift is shown. Such a shift is depended on antisubstantialistic attitude of transcendental thinking, causing a certain changing of emphasis in philosophical questioning from "What" of dogmatic metaphysic to "How" of critical transcendentalism. Main treatment modes of purity in transcendental discourse are designated, that is eidetic purity, purity of singularity, structure purity and intentional purity.

Key words: purity, transcendental thinking, emptiness, consciousness, intentionality, critique, reduction. 